\title{
PRIMARY LYMPHOMA OF THE LIVER TREATED BY EXTENDED HEPATECTOMY AND CHEMOTHERAPY: A CASE REPORT
}

Eleazar Chaib, Katia Ramos Moreira Leite, Willian Abrão Saad and Joaquim Gama-Rodrigues

CHAIB E et al. - Primary lymphoma of the liver treated by extended hepatectomy and chemotherapy: a case report. Rev. Hosp. Clin. Fac. Med. S. Paulo 57(5):223-228, 2002.

Primary lymphoma of the liver is an extremely rare entity. A case of anaplastic large B-cell (both CD-20 and lambda positive) non-Hodgkin's lymphoma that was confined to the liver in a 33-year-old man is reported. The patient was treated with an extended right hepatectomy and combination chemotherapy: cyclophosphamide, adriamycin, vincristine, and prednisone.

The patient was disease free 24 months after the procedure.

DESCRIPTORS: Liver lymphoma. Surgery. Chemotherapy.

Primary lymphomas of the liver are notably rare $^{1,2}$, and as a result in the past, and even quite recently, they have been diagnosed only at postmortem examination ${ }^{3-5}$.

About 70 patients with this disease have been described in the past 40 years in the literature, but only 16 patients, including our case, have been treated surgically so far.

The predominant histologic description of these lesions includes Bcell lymphomas of the so-called histiocytic type $\mathrm{e}^{5-7}$ or the larged differentiated cell $^{6,8}$. Other variants reported include the lymphocytic type $\mathrm{e}^{3,9-11}$, reticulum cell sarcoma ${ }^{12}$, undifferentiated nonHodgkin's lymphoma ${ }^{4}$, and centroblastic-centrocytic lymphoma ${ }^{13}$.

We report a case of a patient with primary malignant lymphoma of the liver, of B-cell origin, who underwent surgical treatment followed by systemic chemotherapy.

\section{CASE REPORT}

A 33-year-old white man was referred for evaluation of an epigastric mass first noted 3 months previously. Associated with the mass were lethargy, anorexia, and a $6.5 \mathrm{~kg}$ weight loss. The patient denied experiencing fevers, chills, night sweats, nausea, or vomiting. The past medical history was benign, and the patient was on no medications. The physical examination revealed a large palpable, smooth, nontender mass in the right hypochondrium that extended from the costal arch to the umbilicus. The spleen was not palpable, and there were no other abdominal masses. There was no lym-

From the Department of Gastroenterology, Liver and Portal Hypertension Surgery Unit, Hospital das Clínicas, Faculty of Medicine, University of São Paulo. phadenopathy. The remainder of the examination was normal.

Laboratory studies showed the following: serum glutamic oxaloacetic transaminase (SGOT) $32 \mathrm{IU} / \mathrm{L}$, lactic dehydrogenase 1190 IU/L, bilirubin direct $0.4 \mathrm{mg} / \mathrm{dL}$, bilirubin indirect 0.1 $\mathrm{mg} / \mathrm{dL}$, albumin $3.9 \mathrm{~g} / \mathrm{dL}$, prothrombin time $100 \%$, alpha-fetoprotein $16.8 \mathrm{ng} /$ $\mathrm{dL}$, and carcinoembryonic antigen 1.7 ug/L, (Table 1). The other laboratory results were normal.

A computed tomography (CT) scan of the abdomen disclosed a large mass replacing the right lobe of the liver with no other abdominal masses or adenopathy. A chest CT scan was normal. Nuclear magnetic resonance study showed that the mass did not extend into the vena cava or the portal vein (Fig. 1). An arteriogram revealed normal hepatic arterial anatomy. A bone scan was negative for metastases.

Because of the favorable anatomic 
Table 1 - Laboratory data on admission.

\begin{tabular}{ll}
\hline Albumin (4.0-5.0 g/dL) & $3.9 \mathrm{~g} / \mathrm{dL}$ \\
Serum Glutamate Oxalate Transaminase (7-33 IU/L) & $32 \mathrm{IU} / \mathrm{L}$ \\
Serum Glutamate Pyruvate Transaminase (5-30 IU/L) & $16 \mathrm{IU} / \mathrm{L}$ \\
Lactic dehydrogenase (260-480 IU/L) & $1190 \mathrm{IU} / \mathrm{L}$ \\
Bilirubin direct (0.2-1.1 mg/dL) & $0.4 \mathrm{mg} / \mathrm{dL}$ \\
Bilirubin indirect $(0-0.3 \mathrm{mg} / \mathrm{dL})$ & $0.1 \mathrm{mg} / \mathrm{dL}$ \\
Prothrombin time $(>70 \%)$ & $100 \%$ \\
Alpha-fetoprotein $(20 \mathrm{ng} / \mathrm{mL})$ & $16.8 \mathrm{ng} / \mathrm{mL}$ \\
Carcinoembryonic antigen $(8 \mathrm{mg} / \mathrm{L})$ & $1.7 \mathrm{mg} / \mathrm{L}$ \\
\hline
\end{tabular}

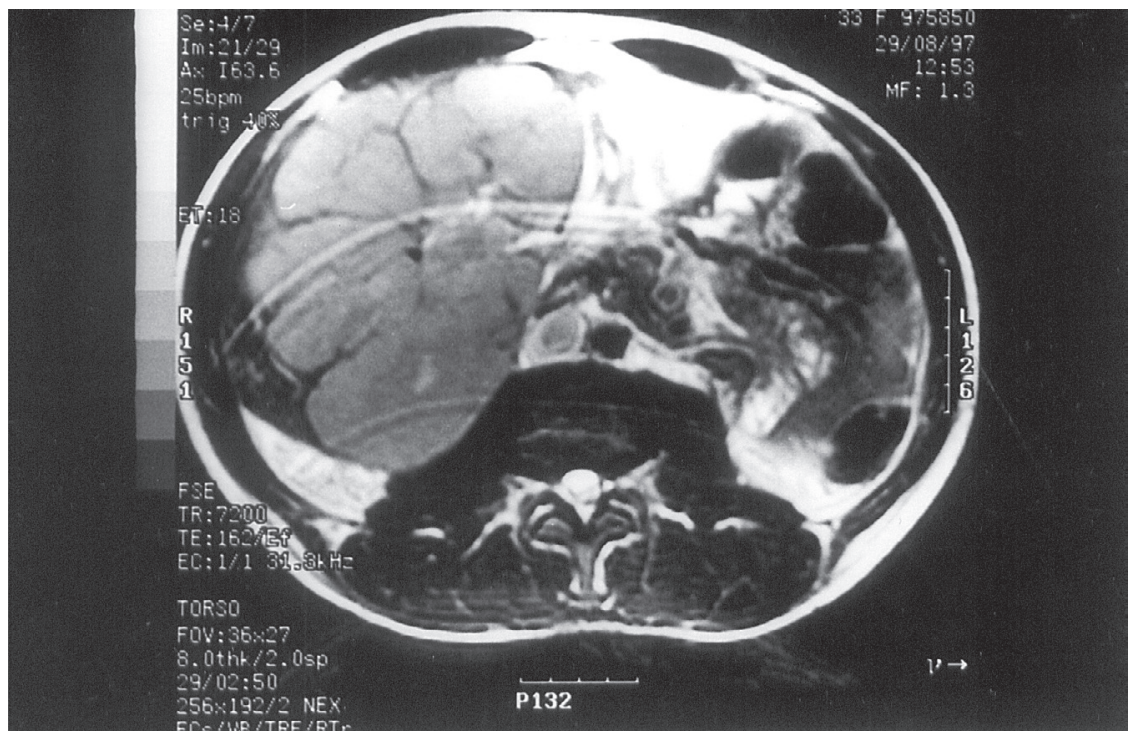

Figure 1 - Nuclear magnetic resonance shows a large, low-density solid mass in the right hepatic lobe of the liver.

location of the tumor and the absence of metastatic disease, an extended right hepatectomy was performed. The resection included the entire right lobe plus segment IVa and IVb. Both the right and middle hepatic veins were taken, leaving about $1 \mathrm{~cm}$ of liver tissue adjacent to the left hepatic vein. The abdominal exploration revealed no evidence of extrahepatic tumor or adenopathy.

After the final pathologic diagnosis, bone marrow and cerebral spinal fluid were examined and found to be free of disease. The patient had mild ascites and right pleural effusion that required pleural punctation because of restrictive pulmonary insufficiency. $\mathrm{He}$ was discharged from the hospital on the $14^{\text {th }}$ postoperative day.

Postoperatively, the patient received systemic chemotherapy of cyclophosphamide, adriamycin, vincristine and prednisone. Twenty-four months after surgery, the patient continues to be free of disease.

\section{PATHOLOGIC STUDY}

The surgical specimen consisted of a right hepatic lobe plus segment IV, weighing $3340 \mathrm{~g}$, and containing a neoplasm of $18 \mathrm{~cm} \mathrm{x} 15.5 \mathrm{~cm}$ x $10 \mathrm{~cm}$. The tumor appeared grayish white, soft, and homogenous, with focal hemorrhage and necrosis. Its border was well circumscribed and lobulated, and appeared to be completely within the limits of resection (Fig. 2).

Microscopically, the liver was composed of an infiltrative diffuse lymphoreticular neoplasia. There was a uniform population of lymphoid cells of large size with many mitotic figures (Fig. 3). The large neoplastic lymphoid cells immunostained positively for leukocyte common antigen and for B-cell markers including CD20. CD-45RO-marked lymphocytes and CD-68-marked macrophages were present within the neoplasm.

The tumor was a large, lambda positive, CD-20 positive, anaplastic malignant B-cell lymphoma. Tests for CD-34, carcinoembryonic antigen, cytokeratin 7, alpha-protein, neurospecific actin, and enolase were negative.

\section{DISCUSSION}

The first report of primary hepatic lymphoma was by Ata and Kamal in $1965^{14}$. Primary hepatic lymphoma has been reported in 48 patients ${ }^{15-20}$. Only 2 of these previously reported cases have been children ${ }^{16}$.

The review of the literature reveals that primary lymphoma of the liver occurs in a wide age range ( 7 to 84 years) and has been reported mainly in male patients. The gross involvement of the liver is of 1 or several nodules, and microscopically the dominant type is the large cell histiocytic type ${ }^{15}$.

The cellular phenotype has been determined in 13 previous cases: $11 \mathrm{~B}$ cell and 2 macrophage. None carried T-cell markers. The phenotype of one of the previous pediatric lymphomas was B-cell and the other was not determined. 


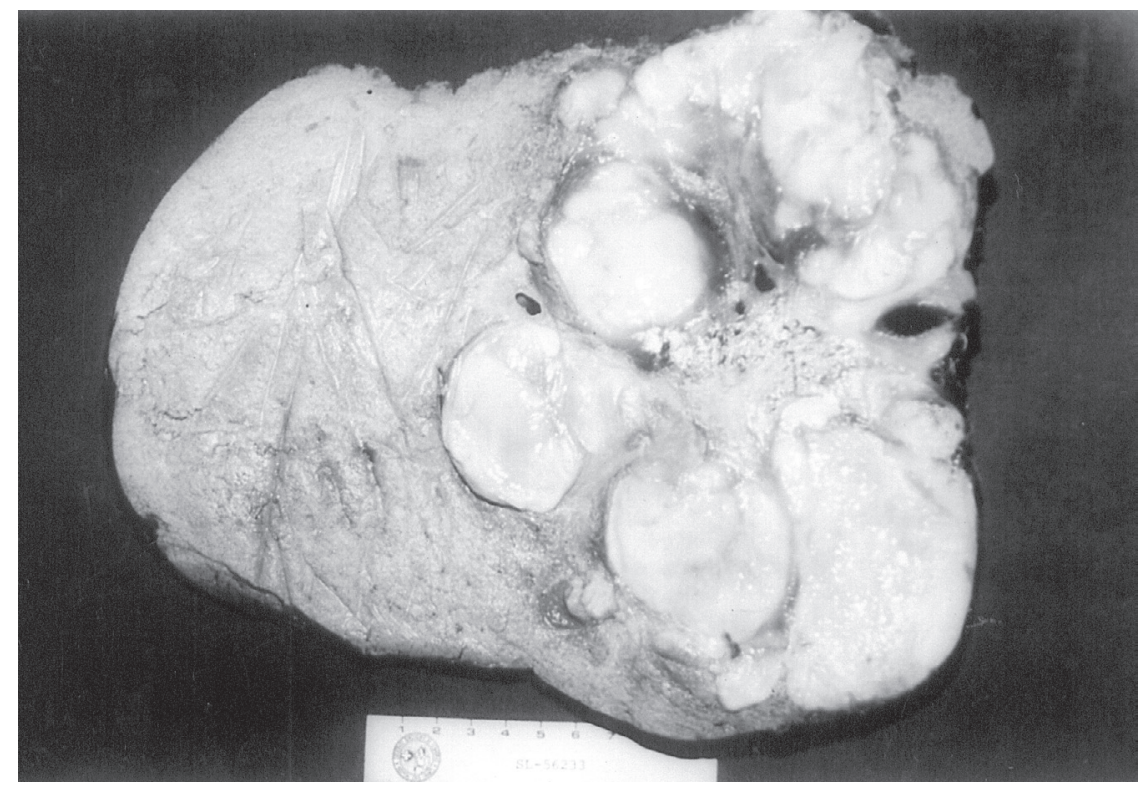

Figure 2 - Cross section of a surgical specimen demonstrate a lobulated tumor $(18 \mathrm{~cm} \mathrm{x} 15.5$ $\mathrm{cm} \times 10 \mathrm{~cm})$. The tumor is yellowish-white in color and elastically hard in consistency.

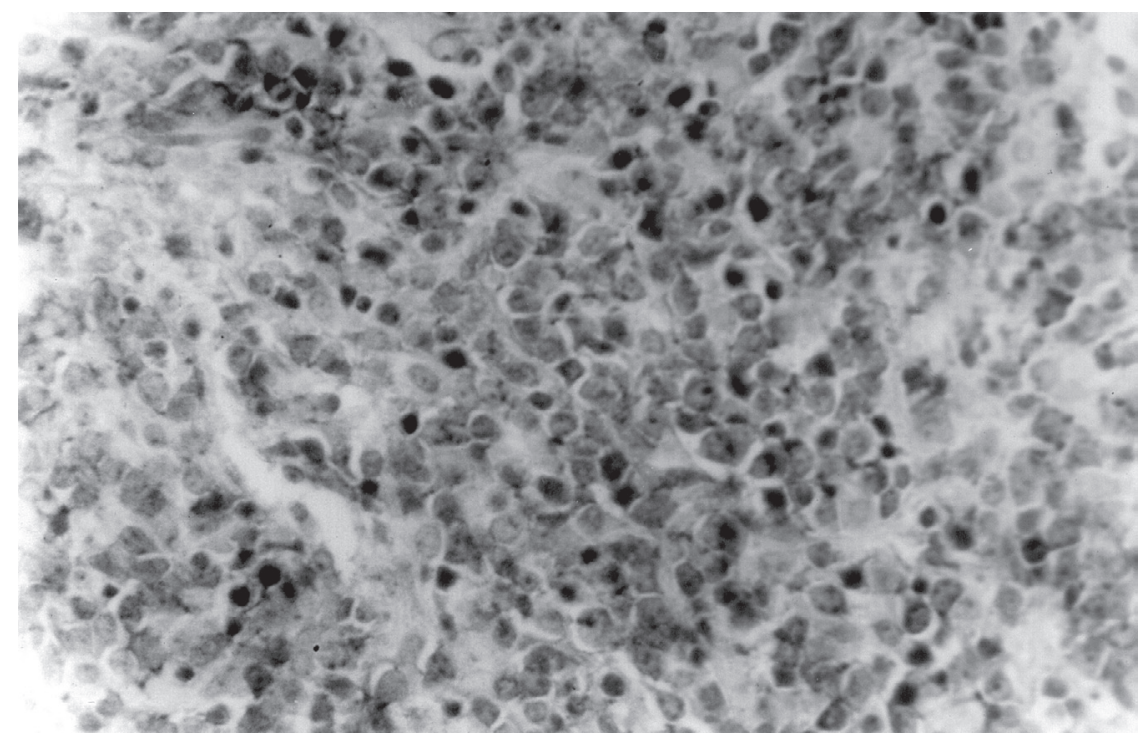

Figure 3 - Microscopic findings show a uniform population of lymphoid cells of large size with many mitotic figures ( $\mathrm{H} \& \mathrm{E}$, original magnification $\mathrm{x} 480)$.

The current case expressed B-cell but not T-cell or macrophage markers. The case satisfies the criteria for a primary hepatic lymphoma as described by Torres and Bollozos ${ }^{3,21}$ and more recently by Strayer et al. ${ }^{5}$.

The clinical presentation of primary lymphoma of the liver has been fairly uniform - middle-aged patients presenting with right upper quadrant or epigastric pain/discomfort in whom hepatomegaly or a tender mass is palpable.

Concerning hepatic resection, the perioperative strategies for reducing morbidity have improved significantly over recent years ${ }^{27-29}$ with a reduction of operative mortality to $3.7 \% 30,31$.

In our case during surgery, there was no evidence of extrahepatic involvement, and the spleen was normal. There was no intra-abdominal adenopathy detected. Therefore, we performed an extended right hepatectomy.

The immediate postoperative period was uneventful except for both mild ascites and pleural effusion, which was treated clinically.

Multi-agent chemotherapy was started 3 weeks after the surgical procedure and was completed within 6 months. The patient was disease free 24 months after the treatment.

According to the more recent literature, treatment of primary hepatic lymphoma varies. For example, 1 patient treated with left hepatic lobectomy alone is disease free ${ }^{7}$. The disease-free survival rate for 5 patients treated with resection and chemotherapy was $80 \% \%^{15,18}$. Of 13 patients treated with chemotherapy alone, $54 \%$ are disease free ${ }^{7,16,20}$.

Two cases reported by Leahy et al. ${ }^{6}$ were treated with chemotherapy; 1 patient had a complete remission and 1 a partial remission.

The importance of surgical resection in localized disease thereby affording a cure or at least a reduction of tumor burden cannot be assessed in this limited series.

Whether or not systemic treatment with chemotherapy will give comparable results to surgery in resectable cases is also not currently known. It seems reasonable to first treat these patients with systemic chemotherapy. If disease persists or only partially regresses in the liver, and there is no evidence of extrahepatic involvement, surgical resection can be performed. We did not perform surgery in this case, because of the extent of the disease, which had spread almost throughout the whole liver (segments IV, V, VI, VII, and VIII ).

Many kinds of treatment, such as chemotherapy, radiation therapy, and percutaneous ethanol injection 
Table 2. Surgically resected primary malignant lymphoma of the liver in the literature.

\begin{tabular}{|c|c|c|c|c|c|c|c|c|c|}
\hline No & Literature & $\begin{array}{l}\text { Age, } \\
\text { Sex }\end{array}$ & Chief complaint & $\begin{array}{l}\mathrm{LDH} \\
\text { (IU/L) }\end{array}$ & $\begin{array}{l}\text { Tumor } \\
\text { Location }\end{array}$ & $\begin{array}{l}\text { Size } \\
(\mathrm{cm})\end{array}$ & Surgery & $\begin{array}{l}\text { Adjuvant } \\
\text { Therapy }\end{array}$ & $\begin{array}{l}\text { Prognosis } \\
\text { (months) }\end{array}$ \\
\hline 1 & Daniel & $60, \mathrm{~F}$ & Fever up & ND & Bilateral lobes & $10 \times 10$ & Extended 1t lobectomy & None & 22, alive \\
\hline 2 & Osborne & $48, \mathrm{~F}$ & RUQ pain & 124 & ND & $4 \times 10$ & Excised & Chemo & 124 , alive \\
\hline 3 & Osborne & $58, \mathrm{M}$ & Abdominal pain & 277 & Lt. lobe & $11 \times 10$ & Excised & Chemo & 20 , alive \\
\hline 4 & Ryoo & $23, \mathrm{M}$ & RUQ pain & ND & Rt. lobe & $7 \times 6 \times 4$ & Rt. Lobectomy & none & 18 , alive \\
\hline 5 & Redondo & $24 \mathrm{~F}$ & Epigastric pain & ND & Lt. lobe & ND & Lt. Lobectomy & Chemo & 21 , alive \\
\hline 6 & Ryan & $65, \mathrm{M}$ & $\begin{array}{l}\text { Epigastric } \\
\text { discomfort }\end{array}$ & 531 & Rt. lobe & $30 \times 25$ & Trisegmentectomy & Chemo & 61 , alive \\
\hline 7 & Ryan & $57, \mathrm{M}$ & Lethargy & 233 & Rt. lobe & $11 \times 9 \times 5$ & Trisegmentectomy & Chemo & 15 , died \\
\hline 8 & Ryan & 49, M & RUQ pain & 248 & Rt. lobe & 10 & Trisegmentectomy & $\begin{array}{l}\text { Chemo+ } \\
\text { radiation }\end{array}$ & 61 , alive \\
\hline 9 & Ryan & $36, \mathrm{M}$ & RUQ pain & 438 & Rt. lobe & $15 \times 15$ & Rt. Lobectomy & Chemo & 53 , alive \\
\hline 10 & Millis & $11, \mathrm{M}$ & $\begin{array}{l}\text { Abdominal } \\
\text { swelling }\end{array}$ & Normal & Rt. lobe & $19 \times 17 \times 12$ & Rt. Lobectomy & Chemo & 30, alive \\
\hline 11 & Andreola & $22, \mathrm{M}$ & RUQ pain jaundice & ND & Rt .lobe & 10 & Trisegmentectomy & None & 62, alive \\
\hline 12 & Pescowitz & $17, \mathrm{M}$ & Epigastric mass & 3770 & Lt.lobe+S8 & $16 \times 14 \times 10$ & $\begin{array}{l}\text { Lt. Lobectomy } \\
\text { S8 partial }\end{array}$ & Chemo & 12 , alive \\
\hline 13 & Hida & $45, \mathrm{M}$ & Epigastric pain & 910 & Lt. lateral lobe & $15 \times 10 \times 7$ & Lt. Lateral segmentectomy & Chemo & 6 , alive \\
\hline 14 & Mitsui & $58, \mathrm{M}$ & RUQ pain & 202 & Lt. lobe & $10 \times 7 \times 7$ & Lt. Lobectomy & Chemo & 36 , alive \\
\hline 15 & Taketomi & $51, \mathrm{M}$ & Free & 1180 & Rt. lobe & $7 \times 6 \times 4$ & Extended rt. Lobectomy & Chemo & 45 , alive \\
\hline 16 & Our case & $33, \mathrm{M}$ & $\begin{array}{l}\text { Lethargy, } \\
\text { weight loss }\end{array}$ & 1190 & Rt. Lobe + S1 & $26 \times 22 \times 10$ & Trisegmentectomy & Chemo & 24, alive \\
\hline
\end{tabular}

ND: not described, LDH: lactic dehydrogenase, RUQ: right upper quadrant, Rt.: right, Lt.: left, Chemo: chemotherapy, M: male, F: female

therapy, have been reported for primary malignant lymphoma of the liver. Previous reports ${ }^{7,8,15,18,22,24-28}$ of 15 patients who underwent hepatic resection are reviewed (Table 2). With the exception of 3 cases, all cases received multi-agent chemotherapy postoperatively. Fourteen were alive at the time of their respective case reports, at intervals ranging from 5 to 124 months (mean 39 months).

Pescovitz et al. ${ }^{24}$ noted that the disease-free survival rate for 5 patients treated with resection and combined chemotherapy was $80 \%$, compared with $54 \%$ survival for chemotherapy alone.
In conclusion, although we do not deny the effectiveness of chemotherapy as shown in some reports ${ }^{7,30,31}$, we consider hepatic resection combined with chemotherapy to be the best method of therapy for this disease in the absence of any extra-hepatic lesions. 
CHAIB E e col. - Linfoma primário do fígado tratado por hepatectomia ampliada e quimioterapia: relato de caso. Rev. Hosp. Clin. Fac. Med. S. Paulo 57(5):223-228, 2002.

O linfoma primário do fígado é uma entidade extremamente rara. Os autores relatam um caso de linfoma não-Hodgkin de células $B$ grandes anaplásicas (positivo para CD-20 e Lambda) em um paciente do sexo masculino de 33 anos. O tumor estava localizado no lobo hepático direito e foi tratado por hepatectomia direita ampliada e quimioterapia pós-operatória com ciclofosfamida, adriamicina, vincristina e prednisone.

Vinte quatro meses de seguimento o paciente encontra-se sem recidiva tumoral.

DESCRITORES: Linfoma hepático. Cirurgia. Quimioterapia.

\section{REFERENCES}

1. ROSEMBERG AS, DIAMOND HD, JASLOWITZ B et al. Lymphosarcoma: A review of 1269 cases. Medicine (Baltimore) 1961; 40: 31-84

2. RUDDERDS RA, ROSS ME \& DeLELLIS RA - Primary extranodal lymphoma: response to treatment and factors influencing prognosis. Cancer 1978; 40: 406-16.

3. TORRES A - Primary lymphocytic follicular lymphoma of the liver. Cancer 1969; 23: 1185-89.

4. CHAMBERS TJ, O'DONOGHUE DP \& STANSFELD AG - A case of primary lymphoma of the liver. J Clin Pathol 1976; 29:96770

5. STRAYER DS, REPPUN TS, LEVIN M et al. - Primary lymphoma of the liver. Gastroenterology 1980; 78:1571-76.

6. LEAHY MF, IBRAHIM EM \& WORTH AJ - Primary hepatic lymphoma. Two case reports and a review of the literature. Med Pediatr Oncol 1982; 10:575-81.

7. DANIEL SJ, ATTIYEH FF, DIRE JJ et al. - A primary lymphoma of the liver treated with extended left hepatic lobectomy. Cancer 1985; 55: 206-09.

8. OSBORNE BM, BUTLER JJ \& GUARD LA - Primary lymphoma of the liver. Ten cases and a review of the literature. Cancer 1985; 56: 2902-10.
9. ALAMI SY, BOWMAN RO, REESE MH et al. - Extranodal lymphosarcoma of the left liver lobe with paraproteinemia. Arch Intern Med 1968; 123:64-68.

10.FRANCILLON J, VIGNAL J, LESBROS F et al. - Lymphossarcome à localisation hepatique pure. Chirurgie 1974; $100: 566-70$.

10.TALAMO TS, DEKKER A, GUREKI J et al. - Primary hepatic malignant lymphoma. Cancer 1980; 46:336-39.

12.TORRES A \& BOZZOLOS GD - Primary reticulum cell sarcoma of liver. Cancer 1971; 27:1489-92.

13.COLLI A, ELLI GM, COCCIOLO $\mathrm{M}$ et al. - Non Hodgkin lymphoma localized in the liver: report of a case without involvement of the other tested districts. Hemotalogica 1986; 71: 229-31.

14.ATA AA \& KAMAL IA - Primary reticulum cell sarcoma of the liver: A case report. J Egypt Med Assoc 1965; 48:514-21.

15.REDONDO C, MARTIN L, CANO AL, CABELLON P, VASQUEZ JM, COLLANTES J - Primary lymphoma of the liver treated with hepatic lobectomy and chemotherapy. Cancer 1987; 60: 736-40.

16.MILLER ST, WOLLNER N, MEYERS PA et al. - Primary hepatic or hepatosplenic non-Hodgkin's lymphoma in children. Cancer 1983; 52:2285-88. 
17.AGHAI E, QUITT M \& LURIE M - Primary hepatic lymphoma presenting as symptomatic immune thrombocytopenic purpura. Cancer 1987; 60: 2308-11.

18.RYAN J, STRAUS DJ, LANGE C et al. - Primary lymphoma of the liver. Cancer 1988; 61:370-75.

19. RUBIN JS, VERCILLO AP \& D'ALOTTO JA - Primary lymphoma of the liver. Conn Med 1987; 51:145-46.

20.DEMENT SH, MANN RB, STAAL SP et al. - Primary lymphomas of the liver. Report of six cases and review of the literature. Am J Clin Pathol 1987; 88 :255-63.

21.ANDREOLA S, AUDISIO RA, MAZZAFERRO V et al. - Primary lymphoma of the liver showing immunohistochemical evidence of $\mathrm{T}$ cell origin. Successful management by right trisegmentectomy. Dig Dis Sci 1988; 33:1632-36.

22.RYOO JW, MANALIGOD LR \& WALKER MJ - Primary lymphoma of the liver. J Clin Gastroenterol 1986; 8: 308-11.

23.MILLIS AE - Undifferentiated primary hepatic non-Hodgkin's lymphoma in childhood. Am J Surg Pathol 1988; 12:721-26.

24.PESCOVITZ MD, SNOVER DC, ORCHARD P et al. - Primary hepatic lymphoma in an adolescent treated with hepatic lobectomy and chemotherapy. Cancer 1990; 65: 2222-26.
25.HIDA J, FUKUHARA T, MARUYAMA J et al. - A case of primary hepatic malignant lymphoma successfully treated by liver resection. J Jpn Soc Clin Surg 1986; 47: 1322-28.

26.MITUSI T, MIURA S, ASADA Y et al. - A cured case of primary hepatic malignant lymphoma. Geka 1986; 48: 745-48.

27.NISHIZAKI T, MATSUMATA T, KAWAKURA T et al. Significance of intraoperative measurement of the liver consistency prior to hepatic resection. Hepatogastroenterol 1995; 42: 5-8

28.HIGASHI H, ADACHI E, MATSUMATA T et al. - Influence of hepatectomy on cell infiltration in the resected liver parenchyma compared with the biopsy specimen - a preliminary study. Hepatogastroenterol 1994; 41: 162-64.

29.ITASAKA H, YAMAMOTO K, TAKETONI A et al. - Influence of blood transfusion on postoperative long-term liver function in patients with hepatocellular carcinoma. Hepatogastroenterol 1995; 42: 465-468.

30.MATSUMATA T, TAKETONI A, KAWAHARA N et al. - Morbidity and mortality after resection in the modern era. Hepatogastroenterol 1995; 42: 456-60.

31.MATSUMATA T, HIGASHI H, SHIMADA M et al. - Indications for major hepatectomy in cirrhotic liver. Hepatogastroenterol 1994; 41:165-69.

Received for publication on September 28, 2002 